\title{
CARACTERIZAÇÃO ISOTÓPICA E BALANÇO HÍDRICO NOS RESERVATÓRIOS DE FRANÇA E DE SÃO JOSÉ DO JACUÍPE
}

\author{
Aderval Barros da Silva \\ Orientador: Dr. Antonio Expedito Gomes de Azevedo (UFBA) \\ 52 p. - Dissertação (Mestrado) - Defesa 27.02.2007
}

\begin{abstract}
RESUMO. Neste trabalho foram medidas as composições isotópicas de amostras de água dos reservatórios de França e de São José do Jacuípe, localizados na sub-bacia do Rio Jacuípe, amostradas em outubro (2003); junho (2004); setembro (2004) e março (2005) em vários pontos das barragens. Além das razões $O^{18} / O^{16}$ e D/H, determinadas no Laboratório de Física Nuclear da UFBa, também foram medidos, in situ, os parâmetros físicoquímicos de condutividade elétrica, sólidos totais dissolvidos, oxigênio dissolvido, temperatura e pH. 0 comportamento das composições isotópicas nos vários pontos amostrados permitiu selecionar um grupo representativo da composição isotópica das barragens, separados dos que apresentaram indicação de interferência local de outras fontes de água. A partir desses pontos representativos foram construídas as linhas de evaporação nos diagramas $\delta O^{18} \times \delta D$ características dos reservatórios. A partir da equação de Rayleigh para a evolução isotópica de um corpo de água em evaporação, incluindo além do fracionamento isotópico de equilíbrio líquido/vapor, o fracionamento cinético em função da umidade relativa do ar, foram calculadas as linhas de evaporação para uma faixa de valores em torno das condições médias de temperatura e umidade relativa do ar características da região. A comparação entre a simulação e os valores observados para a composição isotópica da água nas barragens levou a caracterização, para uma temperatura média de $25^{\circ} \mathrm{C}$ para a região, de uma umidade relativa média de $80 \%$ acima da barragem de França e $85 \%$ acima da barragem de São José do Jacuípe. Baseado no intervalo entre as amostragens do início de junho e meados de setembro de 2004, período em que a quantidade de precipitação na região foi muito pequena, foi calculado a fração do volume evaporado no reservatório de França, correspondente à variação da composição isotópica nesse período, conduzindo a uma evaporação de 10\% do volume acumulado no reservatório de França no início do período considerado. Este resultado foi comparado com os dados hidrológicos disponíveis da ANA e SRH para a região, que apesar da grande incerteza de alguns deles conduzem a um balanço hídrico comparável, mostrando que o acompanhamento isotópico poderá contribuir de uma maneira significativa para a quantificação da evaporação.
\end{abstract}

ABSTRACT. This work presents an isotope based characterization of França and São José do Jacuípe reservoirs localized on the Jacuípe River, tributary of the Paraguaçu River Basin. Thirteen points of the reservoirs were sampled in four occasions, october/2003, june/2004, september/2004 and march 2005. In addition to the measurements of the isotopic ratios ${ }^{18} \mathrm{O} /{ }^{16} \mathrm{O}$ and ${ }^{2} \mathrm{H} /{ }^{1} \mathrm{H}(\mathrm{D} / \mathrm{H})$, it was also measured the physico-chemical parameters of electrical conductivity, total dissolved salts, dissolved oxygen, temperature and $\mathrm{pH}$. The pattern of the isotopic composition of the several sampled points allowed to separate those representative of the isotopic composition of each reservoir from others with interference of local sources of water. From these points, plotted in a ${ }^{18} \mathrm{O}$ versus $\mathrm{D}$ diagram, was obtained the evaporation line characteristic of each reservoir. Using the Rayleigh equation for the isotopic evolution of an evaporating water body including the kinetic fractionation dependent on the atmospheric humidity, besides the equilibrium isotopic fractionation dependent on the temperature, it was simulated the evaporation line for a set of values of temperature and humidity around the typical ones for the region. The comparison between the simulation and the observed data led to the fit, for a temperature of $25^{\circ} \mathrm{C}$, of a humidity of 80\% above the França reservoir and 85\% above the São José do Jacuípe reservoir. Taking the interval between the second and third sampling, when the amount of precipitation in the region was very small, and based on the variation of isotopic composition of the França reservoir observed in this interval, it was calculated the fraction of the volume evaporated, leading to a evaporation of around $10 \%$ of volume in França. This result was compared with data from ANA and SRH agencies for the region that, even though with large uncertainties, lead to a comparable water balance for the period, showing that the isotopic monitoring can contribute to the quantification of the evaporation of reservoirs in our region. 